\title{
INTERACTIONS OF PARTIAL LSD ANALOGS WITH BEHAVIORAL DISRUPTING EFFECTS OF LSD AND DMT IN THE RAT *
}

\author{
† BEVERLY KOVACIC, LEE-JANE WANG LU **, DIANE RUFFING and EDWARD F. DOMINO \\ † The Lafayette Clinic, Department of Pharmacology, 951 E. Lafayette, Detroit, Michigan 48207, and \\ University of Michigan, Department of Pharmacology, Ann Arbor, Michigan 48109, U.S.A.
}

Received 22 July 1977, accepted 29 August 1977

B. KOVACIC, L.J.W. LU, D. RUFFING and E.F. DOMINO, Interactions of partial LSD analogs behavioral disrupting effects of LSD and DMT in the rat, European J. Pharmacol, 47 (1978) 37-44.

Adult male Holtzman rats were trained to barpress on a schedule whereby every fourth press earned a reward of $0.01 \mathrm{ml}$ of sugar-sweetened milk $\left(\mathrm{FR}_{4}\right)$. After an i.p. injection of LSD $(0.1 \mathrm{mg} / \mathrm{kg})$ or DMT (3.2 or $\left.10 \mathrm{mg} / \mathrm{kg}\right)$ such barpressing is abolished completely and resumed, usually within an hour, at a rate near the preinjection control rate of pressing. It continues at a steady, uninterrupted pace until the animals are removed from the operant chamber one-half hour later. A series of $\mathrm{N}, \mathrm{N}$-diethylnipecotamide derivatives were synthesized and tested for their ability to modify the disruptive effect of these hallucinogens. N,N-diethylbutyramide (DBA) and 1-methyl1,2,5,6-tetrahydropyridine-3-(N,N-diethylcarboxamide) (THPC) were also tested. Pretreatment with a single i.p. injection of any of these compounds $(5-40 \mathrm{mg} / \mathrm{kg})$ either had no effect on or else prolonged the duration of hallucinogen-induced cessation of barpressing.

LSD analogs DMT $\quad \mathrm{FR}_{4}$ operant behavior

\section{Introduction}

$\mathrm{N}, \mathrm{N}$-Dimethyltryptamine (DMT) is a psychotomimetic compound which resembles the indoleamine portion of d-lysergic acid diethylamide (LSD) (fig. 1). The drugs show some cross tolerance (Rosenberg et al., 1964; Kovacic and Domino, 1976) and produce similar effects on a variety of responses in several animal species suggesting a common mechanism for their actions. They have common stereochemical and electronic properties (Kang and Green, 1970) which would enable certain corresponding locations on the molecules to attach to the same biologic receptor. For LSD, these locations are ring $A$ and the nitrogen atom of ring $\mathrm{D}$. Corresponding locations

\footnotetext{
* Supported by a grant from the State of Michigan for schizophrenia research to the Lafayette Clinic. ** Present address: Department of Pharmacology, Baylor College of Medicine, Houston, Texas, U.S.A.
}

on DMT are the aromatic benzene ring and the alkylamino nitrogen atom.

A compound which resembles the upper portion of the LSD molecule could conceivably alter a response to LSD and/or DMT by interfering with an action involving the nitrogen atom(s) described above. This speculation was prompted by the resports that 1-methyl1,2,5,6-tetrahydropyridine-N,N-diethylcar-

boxamide (THPC) (fig. 1) blocks the effect of LSD on shock avoidance behavior in rats (Smythies et al., 1970) and on contractions of sheep umbilical vasculature (Dyer et al., 1975).

In the present study, a series of compounds similar to the D ring of the LSD molecule were synthesized and tested for an interaction with LSD or DMT. The compounds are 1-substituted N,N-diethyl nipecotamides (table 1). The methyl derivative is identical to THPC except that it lacks the double bond. THPC and the nipecotamides were tested for their 


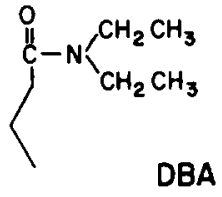

DBA



THPC

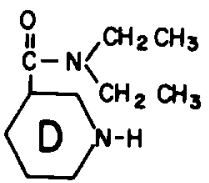

NIPECOTAMIDE
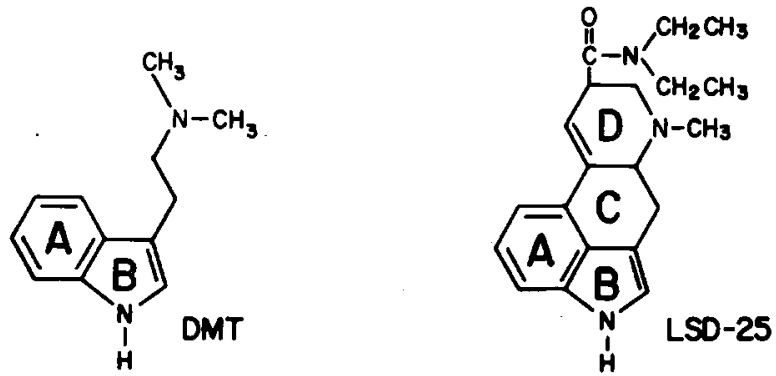

Fig. 1. Chemical structures of partial LSD analogs. DBA, N,N-diethylbutyramide; THPC, 1-methyl-1,2,5,6-tetrahydropyridine-3-(N,N-diethylcarboxamide); nipecotamide, N,N-diethylnipecotamide; DMT, N,N-dimethyltryptamine; LSD, d-lysergic acid diethylamide.

ability to modify the disruptive effects of LSD or DMT on food-rewarded barpressing in rats. $\mathrm{N}, \mathrm{N}$-diethylbutyramide (DBA) (fig. 1), which has been reported to block DMT (Smythies et al., 1972), was also tested.

\section{Materials and methods}

\subsection{Synthesis of compounds}

The 1-substituted N,N-diethylnipecotamides were prepared by the method of $\mathrm{N}$-alkylation. Synthesis of the compounds has been reported previously (Quintana et al., 1965; Quintana and Smithfield, 1967). The earlier preparations were by methods other than the present one. The nipecotamides were isolated as their hydrogen oxalate salts. Melting points were uncorrected.

The compounds were prepared by adding $0.01 \mathrm{~mol}$ of alkyl halide (MeI, EtI, $\mathrm{ClCH}_{2}-$ $\mathrm{CH}=\mathrm{CH}_{2}$ or $\mathrm{C}_{6} \mathrm{H}_{5} \mathrm{CH}_{2} \mathrm{Br}$ ) to a mixture of trace amount of NaI and $0.021 \mathrm{~mol}$ of N,N-diethylnipecotamide in $150 \mathrm{ml}$ of acetonitrile. The mixture was refluxed with stirring for $2 \mathrm{~h}$. Solvent was removed under reduced pressure.
Chloroform $(200 \mathrm{ml})$ was added and the mixture was washed once with $\mathrm{H}_{2} \mathrm{O}(300 \mathrm{ml})$ and once with $10 \% \mathrm{NaOH}(200 \mathrm{ml})$. The chloroform layer was dried (anhydrous $\mathrm{Na}_{2} \mathrm{SO}_{4}$ ), filtered and evaporated to dryness. The oily residue was passed through an aluminum oxide column and eluted with diethyl ether $(700 \mathrm{ml})$. The ether eluate was evaporated to dryness to give an oil from which the hydrogen oxalate salt was prepared. Recrystallization was achieved from a mixture of ether and absolute alcohol. Yield was around 80-90\%. Melting point was uncorrected. Elemental analyses was done by Spang Labs, Ann Arbor, MI. Results are shown in table 1.

\subsection{Rat behavior test}

Male Holtzman rats at least 90 days old were housed individually and maintained at approximately $70 \%$ of their expected free feeding weight. They were trained in commercial operant chambers (Lehigh Valley rodent test cage No. 143-21) to barpress for an hr a day for rewards of $0.01 \mathrm{ml}$ of water-diluted, sugar-sweetened milk. The milk was prepared by combining $400 \mathrm{ml}$ canned, evaporated 
TABLE 1



1-Substituted N,N-Diethylnipecotamides.

\begin{tabular}{|c|c|c|c|c|c|c|c|c|c|}
\hline \multirow[t]{3}{*}{ Compounds 1} & \multirow[t]{3}{*}{$\mathbf{R}$} & \multirow{3}{*}{$\begin{array}{l}\text { Melting } \\
\text { point } \\
\left(0^{\circ} \mathrm{C}\right)\end{array}$} & \multirow{3}{*}{$\begin{array}{l}\text { Formula } \\
\text { (as hydrogen } \\
\text { oxalate salt) }\end{array}$} & \multicolumn{6}{|c|}{ Elemental analysis } \\
\hline & & & & \multicolumn{3}{|c|}{ Calculated } & \multicolumn{3}{|l|}{ Found } \\
\hline & & & & $\mathrm{C}$ & $\mathbf{H}$ & $\mathrm{N}$ & $\mathrm{C}$ & $\mathrm{H}$ & $\mathbf{N}$ \\
\hline Nip-me & $-\mathrm{CH}_{3}$ & $126-8$ & $\mathrm{C}_{13} \mathrm{H}_{24} \mathrm{~N}_{2} \mathrm{O}_{5}$ & 54.40 & 8.38 & - & 54.94 & 8.33 & - \\
\hline Nip-et & $-\mathrm{CH}_{2} \mathrm{CH}_{3}$ & $122-3$ & $\mathrm{C}_{14} \mathrm{H}_{26} \mathrm{~N}_{2} \mathrm{O}_{5}$ & 55.60 & 8.66 & - & 55.51 & 8.63 & 一 \\
\hline Nip-bz & $-\mathrm{CH}_{2} \mathrm{C}_{6} \mathrm{H}_{5}$ & $181-3$ & $\mathrm{C}_{19} \mathrm{H}_{28} \mathrm{~N}_{2} \mathrm{O}_{5}$ & 62.61 & 7.74 & 7.68 & 62.65 & 7.75 & 7.64 \\
\hline Nip-al & $-\mathrm{CH}_{2} \mathrm{CH}=\mathrm{CH}_{2}$ & $135-7$ & $\mathrm{C}_{15} \mathrm{H}_{26} \mathrm{~N}_{2} \mathrm{O}_{5}$ & 57.30 & 8.33 & 8.90 & 57.30 & 8.37 & 8.98 \\
\hline
\end{tabular}

1 Nip-me, 1-Methyl-N,N-diethylnipecotamide; Nip-et, 1-Ethyl-N,N-diethylnipecotamide; Nip-bz, 1-Benzyl-N,Ndiethylnipecotamide; Nip-al, 1-allyl-N,N-diethylnipecotamide.

milk, $400 \mathrm{ml}$ tap water and $60 \mathrm{~g}$ table sugar. The barpressing schedule was fixed ratio-4 $\left(\mathrm{FR}_{4}\right)$ i.e., every fourth press earned a reward. Barpresses and rewards were recorded automatically on cumulative recorders. After each rat's $\mathrm{FR}_{4}$ behavior had stabilized, the rat was exposed to the schedule for an hr a day for at least 5 days before any injections were given.

Doses of hallucinogens $(3.2$ or $10 \mathrm{mg} / \mathrm{kg}$ DMT; $0.1 \mathrm{mg} / \mathrm{kg}$ LSD) known to abolish food-rewarded barpressing completely (Kovacic and Domino, 1976) were selected for use in this study. The effect of an i.p. injection of DMT or LSD on any individual rat was examined by injecting the hallucinogen during a barpressing session and returning the rat immediately to the operant chamber. While barpressing was abolished, a straight horizontal line was generated on the cumulative record. Since recovery from DMT or LSD, as judged by resumption of barpressing, was generally abrupt and complete, the duration of the drug effect could be calculated from the length of the horizontal segment of the cumulative record. After each rat recovered, it was left in the chamber to barpress for at least $30 \mathrm{~min}$.

Rats served as their own controls to com- pare the effect of a hallucinogen with and without pretreatment with an LSD analog. The pretreatment procedure was as follows. A rat was injected (i.p.) with a partial LSD analog. After waiting for $0,5,15$ or $30 \mathrm{~min}$, the rat was placed in an operant chamber, allowed to barpress for 0,5 , or $30 \mathrm{~min}$, injected i.p. with either LSD or DMT and returned immediately to the operant chamber. The total pretreatment time, i.e., the total time between injection of analog and injection of hallucinogen, was either $5,30,45$ or $60 \mathrm{~min}$.

The dose and total pretreatment time used to test THPC (15 mg/kg, $45 \mathrm{~min})$ as an antagonist of LSD $(0.1 \mathrm{mg} / \mathrm{kg})$ and to test DBA (20 $\mathrm{mg} / \mathrm{kg}, 30 \mathrm{~min}$ ) as an antagonist of DMT (10 $\mathrm{mg} / \mathrm{kg}$ ) were the same as those reported by Smythies et al. (1970, 1972). Nipecotamide at $20 \mathrm{mg} / \mathrm{kg}, 60 \mathrm{~min}$ before DMT $(3.2 \mathrm{mg} / \mathrm{kg})$ gave interesting results with the first six animals tested and our plan was to test the entire nipecotamide series under the same conditions. Some of the derivatives, however, by themselves, disrupted the behavior under study at $20 \mathrm{mg} / \mathrm{kg}$, so they were tested at a lower dose $(10 \mathrm{mg} / \mathrm{kg})$ for interaction with 
the hallucinogens. The benzyl derivative, although inactive by itself at $20 \mathrm{mg} / \mathrm{kg}$, prolonged the effects of LSD and DMT. It was then tested at a lower dose $(5 \mathrm{mg} / \mathrm{kg})$ and at a shorter pretreatment time $(5 \mathrm{~min})$.

Tables 2,3 and 4 summarize doses, pretreatment times, and numbers of animals used to test the various drugs for ability to alter reactions to LSD or DMT.

Other groups of 4 to 7 rats were used to demonstrate that the drug pretreatments by themselves (at the same doses and pretreatment times used to test for interaction) had no effect on the behavior under study.

A total of 120 trained rats were kept for several months and used several times in the study. The animals were randomly assigned to the various drug groups with intervening drugfree intervals of at least one week. An exception to the last statement is that after a control injection of DMT alone, less that a full week was allowed as a drug-free interval since DMT is known to have a very short duration of action. For each test of interaction in an individual rat, a corresponding control reaction to hallucinogen alone was obtained either before or after the interaction test with an intervening drug-free interval as described above.

At the beginning of the study, control reactions to hallucinogens without pretreatment with analogs were obtained by substituting an injection of physiologic saline $(0.9 \% \mathrm{NaCl})$ for the analog injection. Saline does not alter reactions to LSD or DMT and in most of the study, control reactions were obtained with no pretreatment at all.

DMT is known to be relatively ineffective when administered orally (Böszörményi and Szara, 1958; Turner and Merlis, 1959). In the present study, results with DMT controls led to the suspicion that a certain percentage of the injections resulted in the drug being delivered into the intestine rather than the peritoneal cavity. The possibility that injections intended to be i.p. could sometimes deliver a drug exclusively into the intestine was tested by injecting ten rats with green ink $(1 \mathrm{ml} / \mathrm{kg})$ by the usual i.p. method. The needle (26 gauge, $3 / 8$ inch) of the injection syringe was thrust into the abdomen slightly lateral to the midline at points below the diaphragm and above the bladder; the plunger was aspirated before the fluid was injected. Immediately after injection, the animals were decapitated, an incision made in the abdomen, the viscera exposed and examined. To minimize the possibility that the animals would struggle during decapitation and cause rapid dispersal of the ink, they were sedated with pentobarbital (30 $\mathrm{mg} / \mathrm{kg}$ ) about $5 \mathrm{~min}$ before the ink injection.

In one group of six rats, the effect of orally administered DMT was examined by allowing the animals to barpress for $30 \mathrm{~min}$, injecting $10 \mathrm{mg} / \mathrm{kg}$ orally and returning the animals immediately to the operant chambers. They were removed from the chambers $45 \mathrm{~min}$ later.

\section{Results}

The pattern of response to LSD or DMT was the same with and without pretreatment with LSD analogs (except for unsubstituted nipecotamide which will be discussed separately below). Typically, within a minute or two after injection of DMT or at about $5 \mathrm{~min}$ after injection of LSD, a rat would suddenly stop barpressing. It would resume, usually rather abruptly, within an hour at a rate near the pre-hallucinogen control rate of pressing. It would then continue barpressing at a steady pace for at least half an hour.

Table 2 shows results obtained with LSD. It can be seen that interanimal variability is high, mean durations of control reactions for the various groups (last column) ranging from 25 to $49 \mathrm{~min}$. Nip-et and Nip-bz significantly prolonged the duration of LSD-suppression when given $60 \mathrm{~min}$ before the hallucinogen but not if given only $5 \mathrm{~min}$ before.

DMT did not invariably abolish barpressing in otherwise undrugged animals. The results of 183 control injections of DMT $(3.2 \mathrm{mg}$ / $\mathrm{kg}$ ) obtained in this laboratory over a year's time from this and other studies, were tabu- 
TABLE 2

Duration of LSD-induced $(0.1 \mathrm{mg} / \mathrm{kg})$ disruption of food-rewarded barpressing ${ }^{1}$ in the rat with and without pretreatment with partial LSD analogs.

\begin{tabular}{|c|c|c|c|c|c|}
\hline \multirow{3}{*}{$\begin{array}{l}\text { No. } \\
\text { rats }\end{array}$} & \multicolumn{3}{|c|}{ Pretreatment } & \multicolumn{2}{|c|}{$\begin{array}{l}\text { Duration }(\min ) \text { of LSD-induced disruption } \\
(\text { mean } \pm \text { S.E. })\end{array}$} \\
\hline & \multirow{2}{*}{ Drug 2} & \multirow{2}{*}{$\mathrm{mg} / \mathrm{kg}$} & \multirow[t]{2}{*}{ Time 3} & & \\
\hline & & & & $\begin{array}{l}\text { With pre- } \\
\text { treatment }\end{array}$ & $\begin{array}{l}\text { Without pre- } \\
\text { treatment }\end{array}$ \\
\hline 6 & Nip & 20 & 60 & $27 \pm 3$ & $25 \pm 2$ \\
\hline 4 & Nip-me & 10 & 60 & $40 \pm 7$ & $49 \pm 2$ \\
\hline 4 & Nip-me & 10 & 5 & $44 \pm 6$ & $38 \pm 4$ \\
\hline 4 & Nip-et & 10 & 60 & $50 \pm 74$ & $30 \pm 3$ \\
\hline 5 & Nip-et & 10 & 5 & $50 \pm 8$ & $44 \pm 8$ \\
\hline 5 & Nip-al & 10 & 60 & $40 \pm 6$ & $39 \pm 9$ \\
\hline 5 & Nip-al & 10 & 5 & $39 \pm 7$ & $35 \pm 7$ \\
\hline 5 & Nip-bz & 5 & 60 & $88 \pm 13^{5}$ & $49 \pm 5$ \\
\hline 5 & Nip-bz & 5 & 5 & $55 \pm 12$ & $47 \pm 5$ \\
\hline 5 & Nip-bz & 20 & 60 & $47 \pm 6^{4}$ & $31 \pm 3$ \\
\hline 4 & Nip-bz & 20 & 5 & $55 \pm 17$ & $35 \pm 6$ \\
\hline 9 & THPC & 15 & 45 & $34 \pm 2$ & $29 \pm 3$ \\
\hline
\end{tabular}

$1 \mathrm{FR}_{4}$ schedule (every fourth press earned a reward).

2 Nip, N,N-diethylnipecotamide; Nip-me, 1-methyl-N,N-diethylnipecotamide; Nip-et, 1-ethyl-N,N-diethylnipecotamide; Nip-al, 1-allyl-N,N-diethylnipecotamide; Nip-bz, 1-benzyl-N,N-diethylnipecotamide; THPC, 1-methyl-1,2,5,6-tetrahy dropyridine-3-(N,N-diethylcarboxamide).

3 Minutes between injection (i.p.) of pretreatment and LSD.

4 Significantly different from control $(p<0.05)$.

5 Significantly different from control $(p<0.025)$.

lated. $27(15 \%)$ of the 183 durations of cessation of pressing were zero. The remaining 156 durations (85\%) fall under a normal distribution curve with a mean \pm S.D. of $22.4 \pm 7.7$ $\min$.

To determine if the $15 \%$ could be due to an artifact of injection (intraintestinal rather than i.p.) a group of 10 rats were injected with green ink and the viscera examined. In one $(10 \%)$ of these rats, the ink was found exclusively in a segment (approximately 2.5 $\mathrm{cm})$ of the intestine. When DMT $(10 \mathrm{mg} / \mathrm{kg})$ was administered orally to 6 trained rats, there was no cessation of barpressing. These results suggested that the $15 \%$ zero values were due to intraintestinal rather than i.p. injections. A zero value in a drug-pretreated animal could be due to the pretreatment rather than an artifact of injection. In this study, however, zero values in the drug-pretreated animals represented $7.4 \%$ of the total values, were evenly distributed across groups, and were clearly inconsistent with remaining data in the various groups. Furthermore, as in the control situation, retesting an unaffected animal at a later date invariably produced results consistent with those of the remaining animals in the group. Therefore, in calculating $t$-tests to compare the effect of a hallucinogen with and without pretreatment, zero values were excluded from the calculations.

Table 3 summarizes results obtained with partial structures of LSD tested for an interaction with $3.2 \mathrm{mg} / \mathrm{kg}$ DMT. Only two analogs, Nip and Nip-bz, affected the DMT reaction.

Nip-bz (see last line of table 3 ) significantly prolonged the effect of $3.2 \mathrm{mg} / \mathrm{kg}$ DMT $(p<$ $0.025)$. However, the duration of DMT-induced disruption of barpressing after pretreatment was within one standard deviation of 
TABLE 3

Duration of DMT-induced ( $3.2 \mathrm{mg} / \mathrm{kg}$ ) disruption of food-rewarded barpressing 1 in the rat with and without pretreatment with partial LSD analogs.

\begin{tabular}{|c|c|c|c|c|c|}
\hline \multirow{3}{*}{$\begin{array}{l}\text { No. } \\
\text { rats }\end{array}$} & \multicolumn{3}{|c|}{ Pretreatment } & \multirow{2}{*}{\multicolumn{2}{|c|}{$\begin{array}{l}\text { Duration (min) of DMT-induced disruption } \\
\text { (mean } \pm \text { S.E.) }\end{array}$}} \\
\hline & \multirow{2}{*}{ Drug 2} & \multirow{2}{*}{$\mathrm{mg} / \mathrm{kg}$} & \multirow{2}{*}{ Time ${ }^{3}$} & & \\
\hline & & & & $\begin{array}{l}\text { With pre- } \\
\text { treatment }\end{array}$ & $\begin{array}{l}\text { Without pre- } \\
\text { treatment }\end{array}$ \\
\hline 5 & Nip & 20 & 5 & $26 \pm 3$ & $34 \pm 5$ \\
\hline 12 & $\mathrm{Nip}$ & 20 & 60 & $20 \pm 3$ & $25 \pm 3$ \\
\hline 3 & $\mathrm{Nip}$ & 20 & 60 & See text & $20 \pm 0$ \\
\hline 14 & $\mathrm{Nip}$ & 40 & 60 & $25 \pm 5$ & $29+3$ \\
\hline 6 & Nip-me & 10 & 60 & $26 \pm 1$ & $26 \pm 2$ \\
\hline 5 & Nip-et & 10 & 60 & $25 \pm 5$ & $30 \pm 3$ \\
\hline 6 & Nip-al & 10 & 60 & $21 \pm 1$ & $20 \pm 2$ \\
\hline 6 & Nip-bz & 5 & 60 & $25 \pm 4$ & $24 \pm 2$ \\
\hline 5 & Nip-bz & 20 & 60 & $30 \pm 3^{4}$ & $18 \pm 1$ \\
\hline 6 & DBA & 20 & 30 & $28 \pm 7$ & $21 \pm 1$ \\
\hline 3 & THPC & 20 & 60 & $25 \pm 5$ & $22 \pm 2$ \\
\hline
\end{tabular}

$1 \mathrm{FR}_{4}$ schedule (every fourth press earned a reward).

2 Nip, N,N-diethylnipecotamide; Nip-me, 1-methyl-N,N-diethylnipecotamide; Nip-et, 1-ethyl-N,N-diethylnipecotamide; Nip-al, 1-allyl-N,N-diethylnipecotamide; Nip-bz, 1-benzyl-N,N-diethylnipecotamide; DBA, N,N-diethylbutyramide; THPC, 1-methyl-1,2,5,6-tetrahydropyridine-3-(N,N-diethylcarboxamide).

3 Minutes between injection (i.p.) of pretreatment and DMT.

4 Significantly different from control $(p<0.025)$.
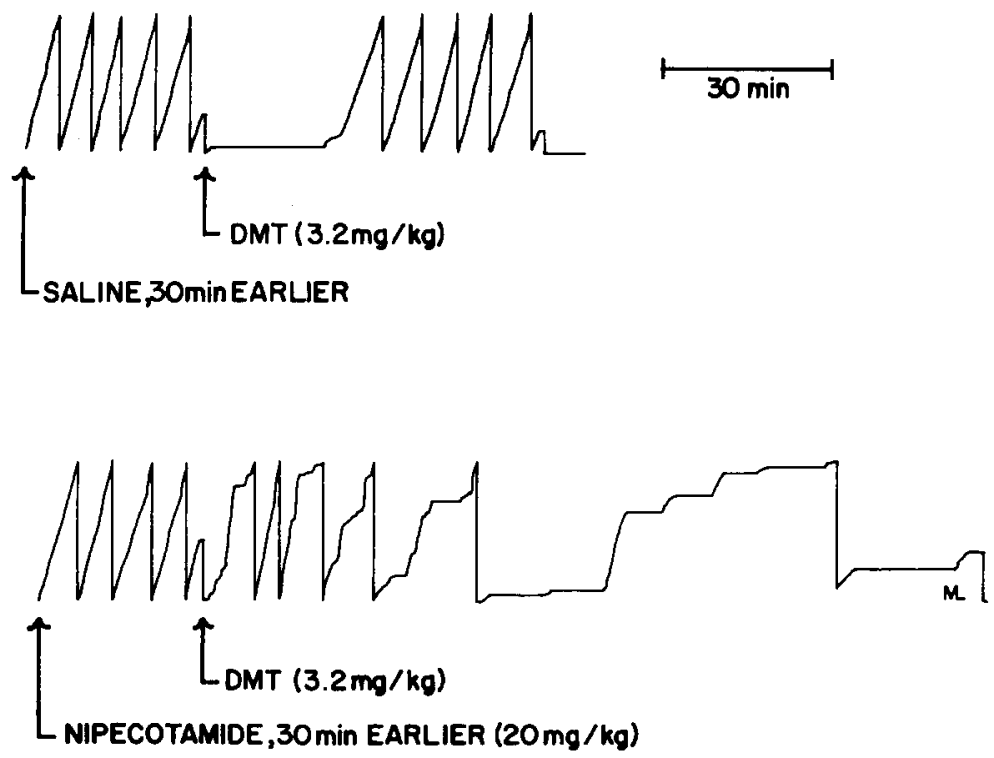

Fig. 2. Cumulative records showing the effect of nipecotamide $(20 \mathrm{mg} / \mathrm{kg})$ on DMT-induced (3.2 mg/kg) disruption of barpressing in a rat. The top record was obtained 3 days before the bottom record. 550 barpresses are required for the pen to advance from the bottom to the top of the page. This type of interaction of nipecotamide and DMT was seen in only 3 of 15 rats. 
TABLE 4

Duration of DMT-induced $(10 \mathrm{mg} / \mathrm{kg}$ ) disruption of food-rewarded barpressing 1 in the rat with and without pretreatment with partial LSD analogs.

\begin{tabular}{|c|c|c|c|c|c|}
\hline \multirow{3}{*}{$\begin{array}{l}\text { No. } \\
\text { rats }\end{array}$} & \multicolumn{3}{|c|}{ Pretreatment } & \multirow{2}{*}{\multicolumn{2}{|c|}{$\begin{array}{l}\text { Duration (min) of DMT-induced disruption } \\
\text { (mean } \pm \text { S.E.) }\end{array}$}} \\
\hline & \multirow{2}{*}{ Drug $^{2}$} & \multirow{2}{*}{$\mathrm{mg} / \mathrm{kg}$} & \multirow{2}{*}{ Time ${ }^{3}$} & & \\
\hline & & & & $\begin{array}{l}\text { With pre- } \\
\text { treatment }\end{array}$ & $\begin{array}{l}\text { Without pre- } \\
\text { treatment }\end{array}$ \\
\hline 5 & DBA & 20 & 30 & $77 \pm 20$ & $48 \pm 2$ \\
\hline 6 & THPC & 10 & 30 & $39 \pm 3$ & $33 \pm 6$ \\
\hline 5 & Nip & 20 & 60 & $50 \pm 10$ & $50 \pm 2$ \\
\hline
\end{tabular}

$1 \mathrm{FR}_{4}$ schedule (every fourth press earned a reward).

2 DBA, N,N-Diethylbutyramide; THPC, 1-methyl-1,2,5,6-tetrahydropyridine-3-(N,N-diethylcarboxamide); Nip, $\mathrm{N}, \mathrm{N}$-diethylnipecotamide.

3 Minutes between injection (i.p.) of pretreatment and DMT.

the average of the normal distribution curve discussed above.

In the case of Nip, 15 rats were injected with $20 \mathrm{mg} / \mathrm{kg} 60 \mathrm{~min}$ before DMT (3.2 $\mathrm{mg} / \mathrm{kg}$ ). Of these 15 rats, 12 gave a response similar to that of their unpretreated control reactions. The other three reacted to DMT in the manner shown by the cumulative record for one of them in the lower half of fig. 2.

Nip, THPC, and DBA were tested against $10 \mathrm{mg} / \mathrm{kg}$ DMT. Results are shown in table 4.

\section{Discussion}

Smythies et al. $(1970,1972)$ reported that THPC and DBA block the effects of LSD and DMT respectively on barpressing to avoid shock. In the present study, THPC and DBA did not block the effects of the hallucinogens on barpressing to obtain food. The difference may in some way be related to the fact that different neurochemical systems are involved in positive versus aversive reinforcement schedules (Stein et al., 1972).

Of drugs in the nipecotamide series, Nip-me and Nip-al did not affect activity of the hallucinogens. Nipet and Nip-bz (after a pretreatment time of 60 but not $5 \mathrm{~min}$ ) shortened the duration of the LSD effect. Nip-bz also shortened the duration of the DMT effect. No explanation is apparent for why nipecotamide $(20 \mathrm{mg} / \mathrm{kg})$ markedly altered the pattern of reaction to DMT in 3 rats (see fig. 2) but did not do so in 12 others. Doubling the dose of nipecotamide did not produce any additional displays of unusual reaction to DMT. Perhaps results obtained with the three exceptional rats are artifactual, but the similarity of the reactions between the 3 rats could argue against this.

It should be noted that nipecotamide and its derivatives have an asymmetric carbon at $\mathrm{C}_{3}$. It is not known which isomers were involved in producing effects seen in this study.

The finding that a sizeable percentage (15\%) of control injections of DMT were without effect, along with evidence that the drug could inadvertently be administered intraintestinally rather than i.p., suggests that in future studies using the i.p. route of administration, data suggesting DMT antagonism be interpreted with caution, especially where small numbers of animals are involved.

\section{References}

Böszörményi, Z. and S. Szara, 1958, Dimethyltryptamine experiments with psychotics, J. Ment. Sci. $104,445$. 
Dyer, D.C., F. Benington and R.D. Morin, 1975, Antagonism of d-lysergic acid diethylamide and mescaline by 1 -methyl-1,2,5,6-tetrahydropyridine$\mathrm{N}, \mathrm{N}$-diethylcarboxamide (THPC), Arch. Intern. Pharmacodyn. 217, 197.

Kang, S. and J.P. Green, 1970, Steric and electronic relationships among some hallucinogenic compounds, Proc. Nat. Acad. Sci. 67, 62.

Kovacic, B. and E.F. Domino, 1976, Tolerance and limited cross-tolerance to the effects of $\mathrm{N}, \mathrm{N}-\mathrm{di}$ methyltryptamine (DMT) and lysergic acid diethylamide-25 (LSD) on food-rewarded bar pressing in the rat, J. Pharmacol. Exptl. Therap. 197, 495.

Quintana, R.P., T.D. Smith and L.F. Lorenzen, 1965, Synthesis of allylnipecotamide, J. Pharm. Sci. 54, 785.

Quintana, R.P. and W.R. Smithfield, 1967, Substituted 1-benzyl-3-(N,N-diethylcarbamoyl)-piperidine cholinesterase inhibitors, Relations between molecular constitution $\mathrm{PKa}$ values and partition coefficients, J. Med. Chem. 10, 1178.

Rosenberg, D.E., H. Isbell, E.J. Miner and C.R. Logan, 1964, The effect of $\mathrm{N}, \mathrm{N}$-dimethyltryptamine in human subjects tolerant to lysergic acid diethylamide, Psychopharmacologia 5, 217.

Smythies, J.R., J. Beaton, F. Benington and R.D. Morin, 1970, Behavioural effects of some derivatives of amphetamine and LSD and their significance, Nature 226, 644.

Smythies, J.R., J.M. Beaton, F. Benington and R.D. Morin, 1972, The design of some new compounds to block psychotomimetic drugs, European J. Pharmacol. 17, 270.

Stein, L., C.D. Wise and B.D. Berger, 1972, in: The Chemistry of Mood, Motivation and Memory, ed. J.L. McGaugh (Plenum Publishing Corp., New York) p. 81.

Turner, W.J. and S. Merlis, 1959, Effect of some indolealkylamines on man, Arch. Neurol. Psychiat. $81,121$. 